Article (refereed) - postprint

Stratford, Charlie; Brewin, Phil; Acreman, Mike; Mountford, Owen. 2015. A simple model to quantify the potential trade-off between water level management for ecological benefit and flood risk.

(C) 2015 European Regional Centre for Ecohydrology of the Polish Academy of Sciences

This manuscript version is made available under the CC-BY-NC-ND 4.0 license http://creativecommons.org/licenses/by-nc-nd/4.0/

(cc) EY-NC-ND

This version available http://nora.nerc.ac.uk/513287/

NERC has developed NORA to enable users to access research outputs wholly or partially funded by NERC. Copyright and other rights for material on this site are retained by the rights owners. Users should read the terms and conditions of use of this material at http://nora.nerc.ac.uk/policies.html\#access

NOTICE: this is the author's version of a work that was accepted for publication in Ecohydrology and Hydrobiology. Changes resulting from the publishing process, such as peer review, editing, corrections, structural formatting, and other quality control mechanisms may not be reflected in this document. Changes may have been made to this work since it was submitted for publication. A definitive version was subsequently published in Ecohydrology and Hydrobiology (2015), 15 (3). 150-159.

10.1016/j.ecohyd.2015.06.002

www.elsevier.com/

\author{
Contact CEH NORA team at \\ noraceh@ceh.ac.uk
}

The NERC and CEH trademarks and logos ('the Trademarks') are registered trademarks of NERC in the UK and other countries, and may not be used without the prior written consent of the Trademark owner. 


\title{
A simple model to quantify the potential trade-off between water level management for ecological benefit and flood risk.
}

\author{
Charlie Stratford ${ }^{\mathrm{a}^{*}}$, Phil Brewin ${ }^{\mathrm{b}}$, Mike Acreman ${ }^{\mathrm{a}}$ \& Owen Mountford ${ }^{\mathrm{a}}$. \\ ${ }^{a}$ Center for Ecology and Hydrology, Wallingford, Oxfordshire, UK \\ ${ }^{b}$ Somerset Drainage Board Consortium, Highbridge, Somerset, UK \\ ${ }^{*}$ Corresponding author. Address: Center for Ecology and Hydrology, Maclean Building, Crowmarsh \\ Gifford, Wallingford, Oxfordshire, OX10 8BB, UK. Tel.: +44 1491692413. \\ Email address: cstr@ceh.ac.uk (C. J. Stratford)
}

\section{Acknowledgements}

This study was conducted with the support and funding of the Somerset Drainage Board Consortium. Additional funding was provided by the Natural Environment Research Council. The authors wish to acknowledge the following people for their help in carrying out this work: Nick Stevens and lain Sturdy (Somerset Drainage Board Consortium), Keith Fifield, Murray Bush and Christopher Matthews (Environment Agency) and Richard Archer (Royal Society for the Protection of Birds).

\section{Abstract}

Throughout the world, historic drainage of wetlands has resulted in a reduction in the area of wet habitat and corresponding loss of wetland plant and animal species. In an attempt to reverse this trend, water level management in some drained areas is trying to replicate a more natural 'undrained' state. The resulting hydrological regime is likely to be more suitable to native wetland species; however the raised water levels also represent a potential reduction in flood water storage capacity. Quantifying this reduction is critical if the arguments for and against wetland restoration are to be discussed in a meaningful way. We present a simple model to quantify the hydrological storage capacity of a drainage ditch network under different water level management scenarios. The model was applied to the Somerset Levels and Moors, UK, comparing areas with and without raised water level management. The raised water level areas occupy $11 \%$ of the maximum theoretical storage but when put in the context of the recent severe flooding of winter 2013/2014 occupy only $0.6 \%$ of the total flood volume and represent an average increase in flood level of 7 $\mathrm{mm}$. These results indicate that although the raised water level scheme does occupy an appreciable volume of the maximum possible ditch storage, in relation to a large flood event the volume is very small. It therefore seems unlikely that the severity of such large flood events would be significantly reduced if the current water level management for ecological benefit ceased.

Keywords: wetland; flooding; Somerset Levels and Moors; pumped catchment; model

\section{Introduction}

Grazing marshes have assumed a significant role in the conservation of British wetlands representing a stage in the conversion of 'virgin' land into farmland (Mountford, 1994). As such they support 
vegetation that is neither typical of primeval wetland nor of intensive cultivation (Moss 1907; Williams 1970). In the ancient undrained wetland wild grazing animals (e.g. horses, deer) would have helped maintain the herbaceous vegetation (arresting scrub invasion), but their place was taken by livestock as the wetlands were ditched and converted to grazing marsh. Since the Roman occupation, freshwater grazing marshes have been created both by the enclosure of high coastal saltmarsh and the drainage of inland mires, and now such areas are typically permanent pasture, intersected by a network of drainage channels (Williams and Hall, 1987). Drainage and land use change have modified or destroyed large areas of wetland in England and the loss of wetland species has been observed over many years (Mountford, 1994). Drainage, leading to subsidence and peat decomposition, can also significantly alter soil hydraulic properties, including water retention, hydraulic conductivity and specific yield, and in turn reduce the wetland's capacity to regulate the hydrological cycle (Price and Schlotzhauer, 1999; Kellner and Halldin, 2002; Kennedy and Price, 2005, Acreman and Holden, 2013).

To address the negative impacts of drainage, encouragement has been given to land owners to maintain water levels in ditches typical of a natural annual cycle (i.e. high water levels in winter and low water levels in summer) with the hope that a more 'natural' regime will support increased numbers of wetland species. Raised water levels in ditches can produce a high soil water table and as such are effective for promoting the desired wet conditions. This management practice was especially promoted by agri-environment schemes such as the Somerset Levels and Moors Environmentally Sensitive Area (ESA) and there is evidence that this initiative has at least arrested the decline of some wetland species (Swetnam et al. 2004). Whilst raising water levels may support delivery of some ecosystem services, others may be lost or reduced. Acreman et al., (2011) looked at the effect of various management practices on the extensively drained Somerset Levels and Moors and found that raised water levels increased delivery of services, such as carbon sequestration, climatic regulation, biodiversity (in the long term) and recreation and education. They also found that food production, freshwater availability, biodiversity (in the short term) and flood storage were reduced. It is flood storage that is the particular focus of this paper.

Effective management of hydrological systems requires a quantified understanding of the impact of management on the service(s) in question, and a combination of monitoring and modelling is likely to underpin that understanding. A conceptual model is the first step in identifying which elements should be included in the study and an iterative process then takes place whereby the model is tested numerically and altered and/or refined as necessary in order to improve the representation of reality (Acreman and Miller, 2007). Depending on the nature of the study area, model development can be highly complex and time consuming. Various models for predicting in-field water tables exist ranging in complexity from empirical ditch-drainage equations (e.g. Youngs, 1985) which relate water table height to rainfall, drain spacing and hydraulic conductivity (Equation 1) to complex groundwater/surface water models such as MIKE-SHE (DHI, Hørsholm, Denmark), which provide numerical solutions to both unsaturated and saturated processes.

Equation 1 Steady-state drainage equation where $H_{m}$ is the mid-drain water-table height, $D$ is the drain spacing, $q$ is the steady-state rainfall rate, $\mathrm{K}$ is the hydraulic conductivity and $\alpha$ is a factor dependent upon the position of an impermeable barrier (Youngs, 1985).

$$
H_{m} /_{D}=(q / K)^{1 / \alpha}
$$


However for a catchment containing many thousands of separate fields and hundreds of $\mathrm{km}$ of ditches, a catchment-wide fully distributed application of either of these modelling approaches model is likely to take considerable time and require detailed input data, and may therefore be unsuitable for many applications. A rapid yet robust approach is desirable in situations that require management questions to be answered quickly and with confidence.

In this study, we developed a simple model of ditch and soil water storage. The model was applied to the winter 2013/2014 floods in the Somerset Levels and Moors to quantify the reduction in flood storage volume resulting from the maintenance of raised water levels. The volumes calculated using the model were assessed in relation to direct rainfall, instantaneous flood volume and inflow volume. In relation to the $2013 / 2014$ floods, our initial hypothesis to be tested was that the impact of the raised water level areas was minimal and that the main driver of flooding was unusually high rainfall.

\section{Methods}

\subsection{The Model}

A simple hydrological storage model has been developed to provide rapid quantitative assessment of hydrological storage volume in a landscape dominated by drainage channels and permeable soils. Storage is available in both the ditches themselves and in the soil adjacent to the ditches. The conceptual basis for this model comes from observations of water table elevation from Tadham Moor (on the Somerset Levels and Moors). When rainfall consistently exceeds evapotranspiration a dome-shaped water table forms sloping downward from field centre to bounding ditch. When evaporation consistently exceeds rainfall a bowl-shaped water table forms sloping from bounding ditch to field centre. The model is developed specifically for application to wet winter conditions when evaporation is small in comparison to rainfall and the hydrological gradient is towards the ditch. It does not account for any topographic variation and assumes that parameters are uniform across the study area.

Rather than attempting to produce a dynamic model that computes the volumes of water moving through the study site and how those volumes change with time, a steady-state approach is taken. The model consists of two elements, within channel storage and soil storage. The total storage per unit length of ditch is calculated as the sum of the two elements.

Storage component 1: the available volume in the surface water body $\left(m^{3} \cdot m^{-3}\right)$. Calculated by multiplying the width of surface feature by the vertical distance from ditch water level to the adjacent land surface (i.e. the depth of water required to fill the ditch).

Storage component 2: the available volume in the soil profile $\left(\mathrm{m}^{3} \cdot \mathrm{m}^{-3}\right)$. Instead of using hydraulic conductivity to calculate the flux into and out of the soil, the parameter 'Extent of influence' is used to describe the width of soil away from the ditch that is likely to receive water from the ditch during a flood event. The storage is then calculated by multiplying the extent of influence by a factor describing the active pore space of the soil (the likely available volume to receive water). A simple 
straight line approximation of the shape of the water table is used. At the ditch/soil interface this is equal to the ditch water level, and it meets the soil surface at the distance defined as extent of influence (Figure 1).

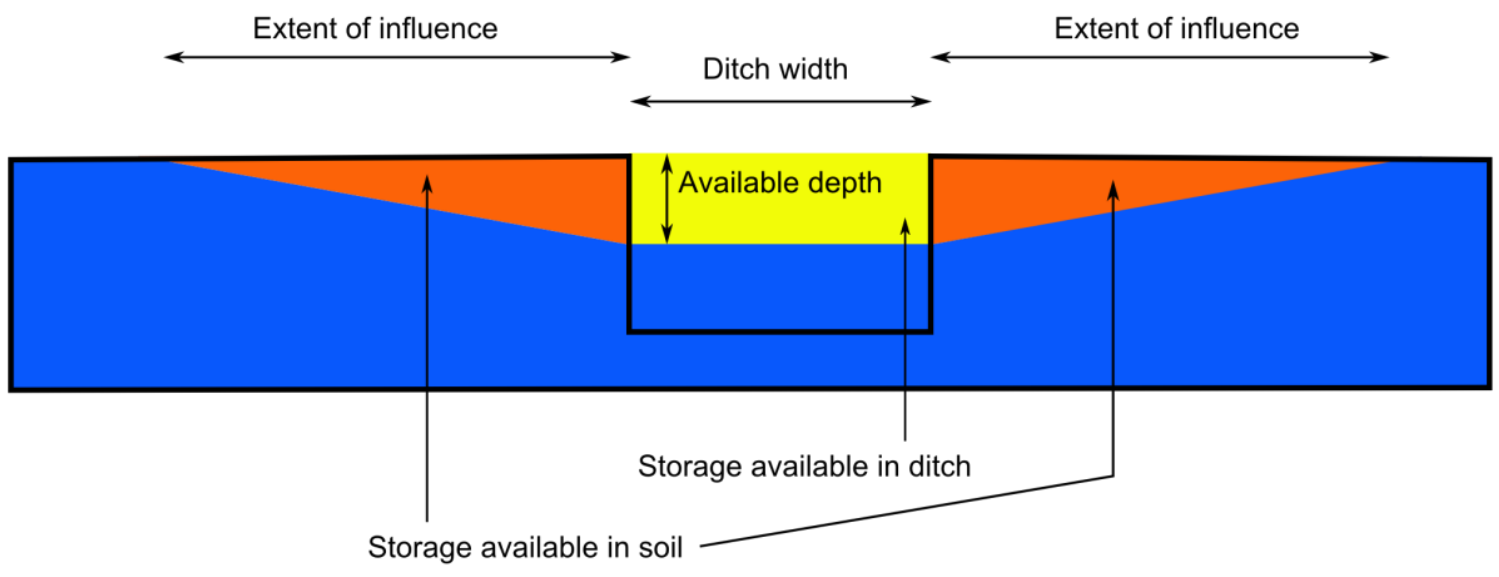

Figure 1 The two storage elements required in the calculation of total ditch storage. Yellow shading indicates the available storage capacity in the ditch and orange shading indicates the available storage capacity in the soil. The blue shading indicates the water level in the ditch and saturated soil. The water level in the ditch has an influence on the adjacent soil water table.

The sum of storage components 1 and 2 gives the total storage per metre and this is multiplied by the total ditch length to give the total storage volume. The final output from the model is the total storage volume and by comparing this for a range of water level management scenarios the difference in available storage between scenarios can be calculated.

An important aspect of the model design is that it assumes the presence of a low permeability layer underneath the permeable soils such that there is no vertical movement of groundwater and that aquifer storage does not play a significant role in the local storage of surface water. This is not uncommon in the drained lowland permeable landscapes. The simplicity of this model and moderate data requirements make it well suited to rapid application over large areas.

\subsection{Data analysis}

For the calculated storage volumes to have relevance to flood risk management, they are expressed in relation to other hydrological volumes. The perspective that this gives helps to underpin any conclusions as to the likely impact on total storage of the water level management practice in question. The hydrological volumes selected for comparison, and their associated advantages and disadvantage, are described in Table 1.

Table 1 Hydrological volumes calculated for comparative purposes

\begin{tabular}{|l|l|l|l|}
\hline $\begin{array}{l}\text { Hydrological } \\
\text { volume name }\end{array}$ & Description & Advantages & Disadvantages \\
\hline Direct Rainfall & $\begin{array}{l}\text { For the study period, } \\
\text { total rainfall is multiplied }\end{array}$ & $\begin{array}{c}\bullet \text { Relatively quick and } \\
\text { easy to calculate. }\end{array}$ & $\begin{array}{l}\bullet \text { Doesn't account for } \\
\text { inflows from upstream }\end{array}$ \\
\hline
\end{tabular}




\begin{tabular}{|c|c|c|c|}
\hline & $\begin{array}{l}\text { by area to give the total } \\
\text { volume of water falling } \\
\text { on the study area. }\end{array}$ & $\begin{array}{l}\text { - Data are generally } \\
\text { available }\end{array}$ & $\begin{array}{l}\text { and is therefore likely to } \\
\text { be an underestimate. }\end{array}$ \\
\hline $\begin{array}{l}\text { Estimated flood } \\
\text { volume }\end{array}$ & $\begin{array}{l}\text { For a point in time, the } \\
\text { aerial extent of flooding is } \\
\text { measured. } \\
\text { A flood volume/area/ } \\
\text { depth relationship is } \\
\text { developed from analysis } \\
\text { of the corresponding } \\
\text { digital surface model. } \\
\text { The two are combined to } \\
\text { estimate flood volume } \\
\text { from aerial flood extent. }\end{array}$ & $\begin{array}{l}\text { - For a point in time, } \\
\text { provides a 'measured' } \\
\text { flood volume. } \\
\text { - The elevation data } \\
\text { required are often } \\
\text { available. }\end{array}$ & $\begin{array}{l}\text { - A single 'snapshot' that } \\
\text { doesn't account for } \\
\text { rainfall or inflow. } \\
\text { - The aerial extent data } \\
\text { may require using } \\
\text { moderately costly } \\
\text { monitoring techniques } \\
\text { such as aerial image } \\
\text { acquisition for large } \\
\text { areas, or standard } \\
\text { surveying of the water's } \\
\text { edge for small areas. }\end{array}$ \\
\hline $\begin{array}{l}\text { Apportioned } \\
\text { inflows }\end{array}$ & $\begin{array}{l}\text { Available flow data are } \\
\text { scaled-up according to } \\
\text { catchment size in order } \\
\text { to quantify the total } \\
\text { inflow to the study area. } \\
\text { The total inflow is then } \\
\text { apportioned between the } \\
\text { units. }\end{array}$ & $\begin{array}{l}\text { - Gives a more accurate } \\
\text { measure of inflow } \\
\text { volume. } \\
\text { - Flow data are } \\
\text { available for many } \\
\text { major water courses. }\end{array}$ & $\begin{array}{l}\text { - Required specialist } \\
\text { hydrological knowledge } \\
\text { of both the concept \& } \\
\text { study area. } \\
\text { - Data limitations may } \\
\text { introduce uncertainty. }\end{array}$ \\
\hline
\end{tabular}

\subsection{The Study Site}

The trial application of this model was carried out in the Somerset Levels and Moors (from henceforth referred to as the SLMs), in the south west of the UK (Figure 2). 


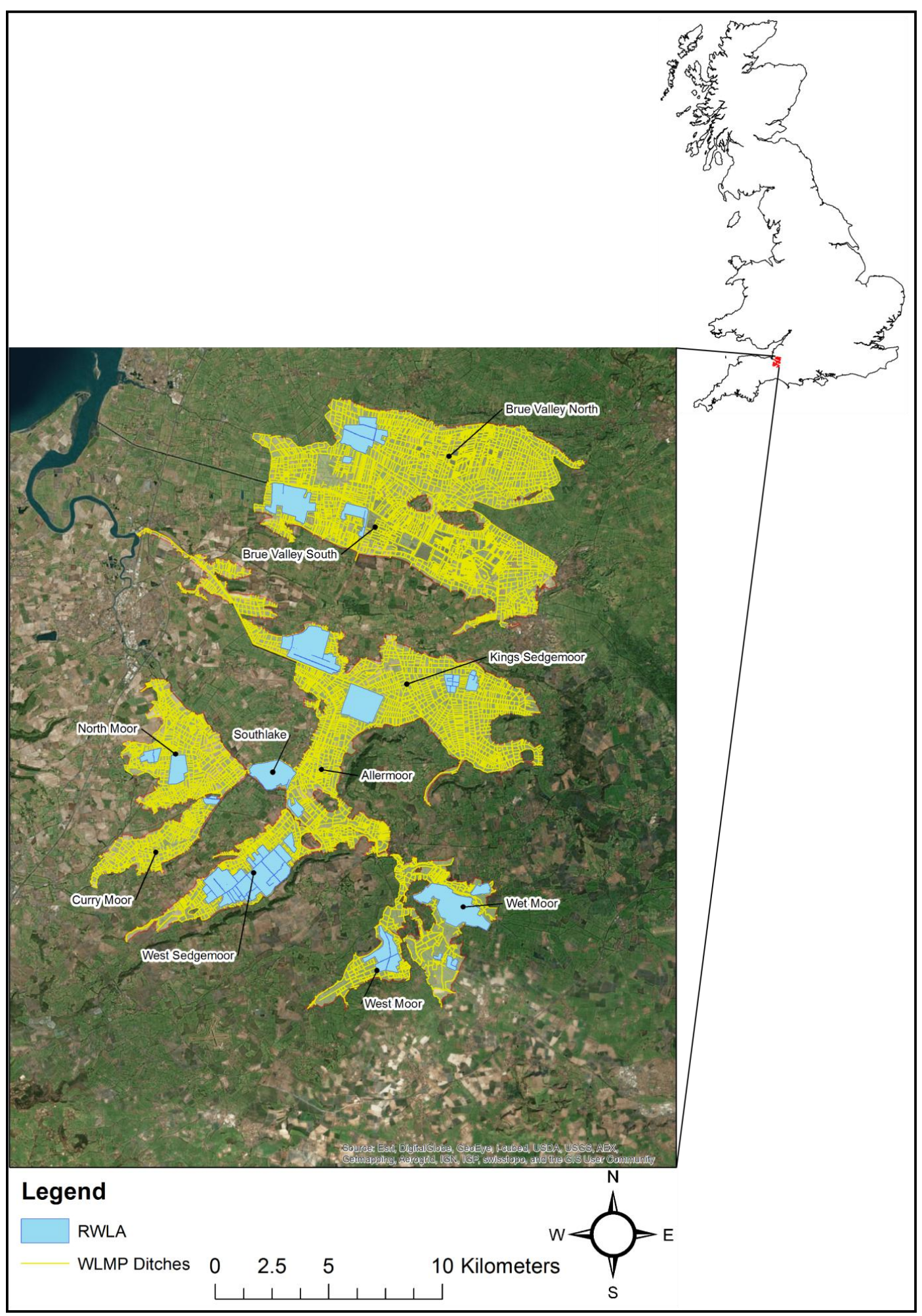

Figure 2 The location of the Somerset Levels and Moors in the UK, and detailed view of the Water Level Management Plan areas, and Raised Water Level Areas.

The SLMs cover an area of $650 \mathrm{~km}^{2}$ and consist of low-lying organic peat soils underlain by marine silts and clays, which form an impermeable sub-layer. They are the largest remaining area of lowland wet grassland in England (more than 20\% of the resource) and include 18 Sites of Special Scientific Interest (SSSIs) covering 7200 ha, 12 of which (6300 ha) are Special Protection Areas under 
the European Habitats Directive, with most of the area designated as a Ramsar site under the International Convention on Wetlands (Acreman et al., 2011).

The area is naturally susceptible to flooding, receiving surface water and ground water from the surrounding uplands; the Mendip Hills to the north, the West Wiltshire Downs to the east, the Blackdown Hills to the south and Quantock Hills to the west. Long term (1961 to 2014) average annual rainfall for the area is $852 \mathrm{~mm}$. The movement of water to the sea by gravity is hindered due to the low-lying nature of the SLMs, which in places are only 3 to $4 \mathrm{~m}$ above Ordnance Datum (OD) and 4-5 $\mathrm{m}$ below high tide levels. The water that collects in the low-lying areas is directed, via the network of drainage channels, towards pumping stations that lift the water into a network of embanked rivers that act as high level carriers to convey the water to the Bristol Channel.

The network of drainage channels is divided into 10 Water Level Management Plan (WLMP) areas, and within each area the watercourse network is classified by size as either: Main river, Viewed Rhyne or Ordinary watercourse. Field surveys conducted in 2014 generated estimates for the widths of each and GIS analysis was used to find the total length of each watercourse type. Water levels in the watercourses are for the most part managed according to WLMP guidance, with the only exception being a subset of watercourses that are managed as raised water level areas (RWLA). The RWLA were introduced in the SLM ESA with the purpose of 'further enhancing the ecological interests of grassland by the creation of wet winter and spring conditions on the Moors' Tatum (1994). The main difference in management between WLMP and RWLA areas is that winter water levels are held level with the ground surface as opposed to $0.6 \mathrm{~m}$ below (Table 2 ).

Table 2 Winter and summer water levels for Water Level Management Plan and Raised Water Level Areas.

\begin{tabular}{|l|c|c|}
\hline \multirow{2}{*}{ WLMP area } & \multicolumn{2}{|c|}{ Water level relative to soil surface } \\
\cline { 2 - 3 } & $\mathbf{1}^{\text {st }}$ May to $\mathbf{3 0}^{\text {th }}$ November & $\mathbf{1}^{\text {st }}$ December to $\mathbf{3 0}^{\text {th }}$ April \\
\hline RWLA & $-0.3 \mathrm{~m}$ & $-0.6 \mathrm{~m}$ \\
\hline
\end{tabular}

The following water level management regimes were considered:

- Winter ditch storage under current conditions. This assumes that winter water levels in the WLMP watercourses are maintained at $0.6 \mathrm{~m}$ below ground surface, except those in the RWLA, which are maintained at ground surface level.

- Winter theoretical maximum ditch storage. This assumes all WLMP and RWLA watercourses are maintained at $0.6 \mathrm{~m}$ below ground surface level. No ditches are managed with water levels maintained at the ground surface.

- Summer ditch storage. This assumes that all WLMP and RWLA watercourses are maintained at $0.3 \mathrm{~m}$ below ground surface level.

The focal point of this study is the winter flooding of 2013/2014 which was the wettest winter on record for the UK since records began in 1910 (Muchan et al., 2015). For that reason the period from $1^{\text {st }}$ December 2013 to $28^{\text {th }}$ February 2014 inclusive is given particular attention, and is referred to as winter 13/14 from hence forth. The long term (1961 to 2014) average annual rainfall for this period is $239 \mathrm{~mm}$ and the winter $13 / 14$ total is $486 \mathrm{~mm}$. The return period for this period is estimated to be 
50 to 80 years. The result of this rainfall was extensive flooding across the SLMs, much of which persisted for over 6 weeks and caused localised disruption to communities and services, inundation of farmland and houses, with considerable loss to the local economy and serious stress on local communities.

Table 3 Area and length of interest features. (Data provided by Somerset Drainage Board).

\begin{tabular}{|c|c|c|c|c|c|c|c|}
\hline \multirow[b]{2}{*}{ Name } & \multicolumn{2}{|c|}{ Area (ha.) } & \multicolumn{4}{|c|}{$\begin{array}{l}\text { Watercourse length in each Water Level } \\
\text { Management Plan area. Watercourse } \\
\text { length in Raised Water Level Area shown } \\
\text { in brackets. All lengths in km. }\end{array}$} & \multirow[b]{2}{*}{$\begin{array}{c}\text { Percentage of } \\
\text { total length of } \\
\text { watercourse } \\
\text { in WLMP that } \\
\text { is RWLA (\%) }\end{array}$} \\
\hline & $\sum_{3}^{0}$ & 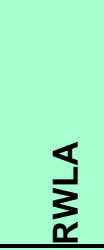 & 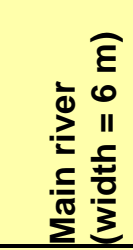 & 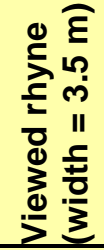 & 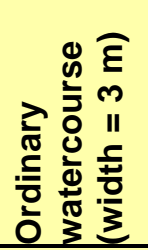 & 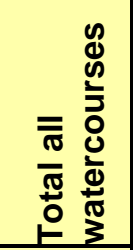 & \\
\hline Allermoor & 902 & 29 & $\begin{array}{r}23.7 \\
(0) \\
\end{array}$ & $\begin{array}{r}19.6 \\
(0)\end{array}$ & $\begin{array}{l}78.1 \\
(2.1)\end{array}$ & $\begin{array}{r}121.4 \\
(2.1)\end{array}$ & 1.7 \\
\hline Brue Valley North & 2926 & 196 & $\begin{array}{r}38.9 \\
(0)\end{array}$ & $\begin{array}{l}70.6 \\
(4.6)\end{array}$ & $\begin{array}{l}287.2 \\
(15.2)\end{array}$ & $\begin{array}{c}396.7 \\
(19.8)\end{array}$ & 5.0 \\
\hline Brue Valley South & 4743 & 298 & $\begin{array}{r}24.7 \\
(0)\end{array}$ & $\begin{array}{r}77.1 \\
(1.6) \\
\end{array}$ & $\begin{array}{l}437.7 \\
(28.3)\end{array}$ & $\begin{array}{r}539.5 \\
(29.9) \\
\end{array}$ & 5.5 \\
\hline Curry Moor & 773 & 19 & $\begin{array}{r}21.0 \\
(0)\end{array}$ & $\begin{array}{r}22.0 \\
(0)\end{array}$ & $\begin{array}{l}64.7 \\
(0.7)\end{array}$ & $\begin{array}{r}107.7 \\
(0.7)\end{array}$ & 0.6 \\
\hline Kings Sedgemoor & 4499 & 588 & $\begin{array}{r}50.3 \\
(0) \\
\end{array}$ & $\begin{array}{r}104.2 \\
(7.7) \\
\end{array}$ & $\begin{array}{l}420.9 \\
(51.4) \\
\end{array}$ & $\begin{array}{c}575.4 \\
(59.1) \\
\end{array}$ & 10.3 \\
\hline North Moor & 1613 & 125 & $\begin{array}{l}7.1 \\
(0) \\
\end{array}$ & $\begin{array}{l}45.9 \\
(2.2) \\
\end{array}$ & $\begin{array}{c}181.8 \\
(15.2) \\
\end{array}$ & \begin{tabular}{|c|}
234.8 \\
$(17.4)$ \\
\end{tabular} & 7.4 \\
\hline Southlake & 206 & 179 & $\begin{array}{r}5.3 \\
(3.0) \\
\end{array}$ & $\begin{array}{r}5.2 \\
(4.9) \\
\end{array}$ & $\begin{array}{r}23.2 \\
(20.6) \\
\end{array}$ & $\begin{array}{r}33.7 \\
(28.5) \\
\end{array}$ & 84.6 \\
\hline West Moor & 541 & 148 & $\begin{array}{l}9.2 \\
(0) \\
\end{array}$ & $\begin{array}{r}13.7 \\
(1.4) \\
\end{array}$ & $\begin{array}{r}45.2 \\
(10.8) \\
\end{array}$ & $\begin{array}{r}68.1 \\
(12.2) \\
\end{array}$ & 17.9 \\
\hline West Sedgemoor & 1576 & 577 & $\begin{array}{l}6.0 \\
(0)\end{array}$ & $\begin{array}{l}47.5 \\
(2.5)\end{array}$ & $\begin{array}{l}159.6 \\
(48.8)\end{array}$ & $\begin{array}{r}213 . \\
(51.3)\end{array}$ & 24.1 \\
\hline Wet Moor & 1487 & 371 & $\begin{array}{l}24.4 \\
(0.8)\end{array}$ & $\begin{array}{l}41.1 \\
(9.5)\end{array}$ & $\begin{array}{r}82.2 \\
(33.4) \\
\end{array}$ & $\begin{array}{c}147.7 \\
(43.7)\end{array}$ & 29.6 \\
\hline Total all areas & 19265 & 2530 & 210.6 & 446.9 & 1780.6 & 2438.1 & \\
\hline
\end{tabular}

\subsection{Application of the model to the SLMs}

With the length and width of each watercourse type in each of the ten WLMP areas established (Table 3), the two remaining parameters to define were specific yield and extent of influence. This was achieved through review of information in the available literature with a particular focus on that collected within the study area. The results of the review are presented here.

Specific Yield. This is generally used interchangeably with the term drainable porosity and is the ratio of the volume of water that drains from a saturated rock or soil by gravity to the total volume of the rock or soil (Meinzer, 1923). Various methods have been employed to establish the specific yield of 
peat soils in the SLM. Gilman (1994) analysed the water table response to rainfall events using the Institute of Hydrology lysimeter at West Sedgemoor (SLM) in autumn of 1990. Analysis of these results suggests a specific yield of $25 \%$. Dawson (2006) determined specific yield at $-1.0 \mathrm{~m}$ pressure potential of samples from West Sedgemoor and found the mean specific yield to be $18 \%$. These values are comparable with those reported by a number of authors for the specific yield of a range of peat soils (Boelter 1968, Letts et al. 2000, Murtedza et al. 2002 and Parkin et al. 2004). Armstrong (1993) reported specific yield values of 5\% for the SLM from an analysis of water level fluctuations. Armstrong and Rose (1999) carried out water level modelling at Southlake Moor (SLM) and used a value of $15 \%$ for the porosity (understood to be drainable porosity in this case) of the peat. They note a two layer system with permeable peaty subsoil overlain in places by less permeable peaty silty topsoil, with a porosity of $12 \%$. An application of the groundwater model MODFLOW (ref) to Tadham Moor found a reasonable calibration of the water level time series was achieved using a specific yield of $20 \%$ noting that 'In general, specific yield values as high as $20 \%$ to $30 \%$ are generally considered typical, although there is a lack of information relating to peat deposits' (Bradford, 2004). The mean and likely range of values is summarised in Table 4.

Table 4 Summary of specific yield values relevant to the study area

\begin{tabular}{|c|c|c|c|c|c|}
\hline Reference & Study type & Study area & Depth (m) & Soil Type & Specific Yield \\
\hline Gilman, 1994. & Lysimeter & $\begin{array}{l}\text { West } \\
\text { Sedgemoor }\end{array}$ & Approx. > 0.1 & & $25 \%$ \\
\hline Dawson, 2006. & Lab sample & $\begin{array}{l}\text { West } \\
\text { Sedgemoor }\end{array}$ & 0 to 0.15 & Peaty loam & $13 \%$ \\
\hline Dawson, 2006. & Lab sample & $\begin{array}{l}\text { West } \\
\text { Sedgemoor }\end{array}$ & 0.35 to 0.50 & $\begin{array}{l}\text { Humified } \\
\text { peat }\end{array}$ & $16 \%$ \\
\hline Dawson, 2006. & Lab sample & $\begin{array}{l}\text { West } \\
\text { Sedgemoor }\end{array}$ & 0.85 to 1.0 & $\begin{array}{l}\text { Semi- } \\
\text { fibrous peat }\end{array}$ & $24 \%$ \\
\hline $\begin{array}{l}\text { Armstrong, } \\
1993 .\end{array}$ & $\begin{array}{l}\text { Water } \\
\text { analysis }\end{array}$ & Whole SLM & Single value & Single value & $5 \%$ \\
\hline $\begin{array}{l}\text { Armstrong and } \\
\text { Rose, } 1999 .\end{array}$ & $\begin{array}{l}\text { Water table } \\
\text { analysis }\end{array}$ & $\begin{array}{l}\text { Southlake } \\
\text { Moor }\end{array}$ & 0 to 0.4 & Clay topsoil & $12 \%$ \\
\hline $\begin{array}{l}\text { Armstrong and } \\
\text { Rose, } 1999 .\end{array}$ & $\begin{array}{ll}\text { Water } & \text { table } \\
\text { analysis } & \\
\end{array}$ & $\begin{array}{l}\text { Southlake } \\
\text { Moor }\end{array}$ & 0.4 to $>2.0$ & $\begin{array}{l}\text { Subsoil } \\
\text { peat }\end{array}$ & $15 \%$ \\
\hline Bradford & $\begin{array}{l}\text { Groundwater } \\
\text { modelling }\end{array}$ & Tadham Moor & & & $20 \%$ \\
\hline
\end{tabular}

Extent of influence. The distance into the field that the ditch has any control over the water table is determined by hydraulic conductivity, which in peat soils is well known to be highly variable in both horizontal and vertical directions. Whilst many studies report values for hydraulic conductivity, relatively few present estimates of 'extent of influence'. Acreman et al. (2002) carried out analysis of water table data from Tadham Moor and concluded that dipwells up to $8 \mathrm{~m}$ from the ditch are influenced by the presence of the ditch, but at locations further away ditch water levels have no impact on water table elevation. Boelter (1972) found that once the water table was drawn down into moderately well-humified (hemic or mesic) peat, the zone of influence of the ditch did not extend beyond $5 \mathrm{~m}$. In less humified (fibric) peat, the hydraulic gradient towards the drain extended 
$50 \mathrm{~m}$. Gilman (2004) collected water table data from West Sedgemoor in 1987 and visual inspection suggests the extent of influence to be $\sim 12 \mathrm{~m}$, although in summer an effect is noted up to $30 \mathrm{~m}$ from the ditch. The mean and likely range of values is summarised in Table 5.

Table 5 Summary of distance of influence and hydraulic conductivity relevant to the study area.

\begin{tabular}{|l|l|l|l|}
\hline Reference & Study area & Distance of influence of ditch (m) & Comment \\
\hline Acreman et al., (2002) & Tadham Moor & $8 \mathrm{~m}$ & \\
\hline Gilman, (2004) & West Sedgemoor & $\begin{array}{l}12 \mathrm{~m} \text {, although a summer effect } \\
\text { up to } 30 \mathrm{~m} \text { from the ditch is } \\
\text { noted. }\end{array}$ & $\begin{array}{l}\text { Well-humified } \\
\text { peat }\end{array}$ \\
\hline Boelter, (1972) & Minnesota, USA. & $5 \mathrm{~m}$ & Less humified peat \\
\hline Boelter, (1972) & Minnesota, USA. & $50 \mathrm{~m}$ & \\
\hline $\begin{array}{l}\text { It is concluded that the likely range of extent of influence for the peat soils in this study is } \mathbf{5} \mathbf{~ m} \text { to } \\
\mathbf{3 0 ~} \mathbf{m} \text { with a likely average value being } \mathbf{9} \mathbf{~ m} .\end{array}$
\end{tabular}

\section{Results}

Land in the SLM managed as RWLA covers 2529 ha or $13.1 \%$ of all WLMP areas and incorporates 264 $\mathrm{km}$, or $10.9 \%$, of all watercourses. The total ditch storage under current conditions totals $6,755,382$ $\mathrm{m}^{3}$ across all areas and varies between units from a minimum volume of $19,206 \mathrm{~m}^{3}$ at Southlake to a maximum volume of $1,606,434 \mathrm{~m}^{3}$ at Kings Sedgemoor in a pattern that reflects the density of ditches in each area. The maximum theoretical ditch storage across all WLMP areas is $7,534,878 \mathrm{~m}^{3}$ and varies between units from a minimum volume of $108,156 \mathrm{~m}^{3}$ at Southlake, to a maximum volume of $1,778,952 \mathrm{~m}^{3}$ at Kings Sedgemoor.

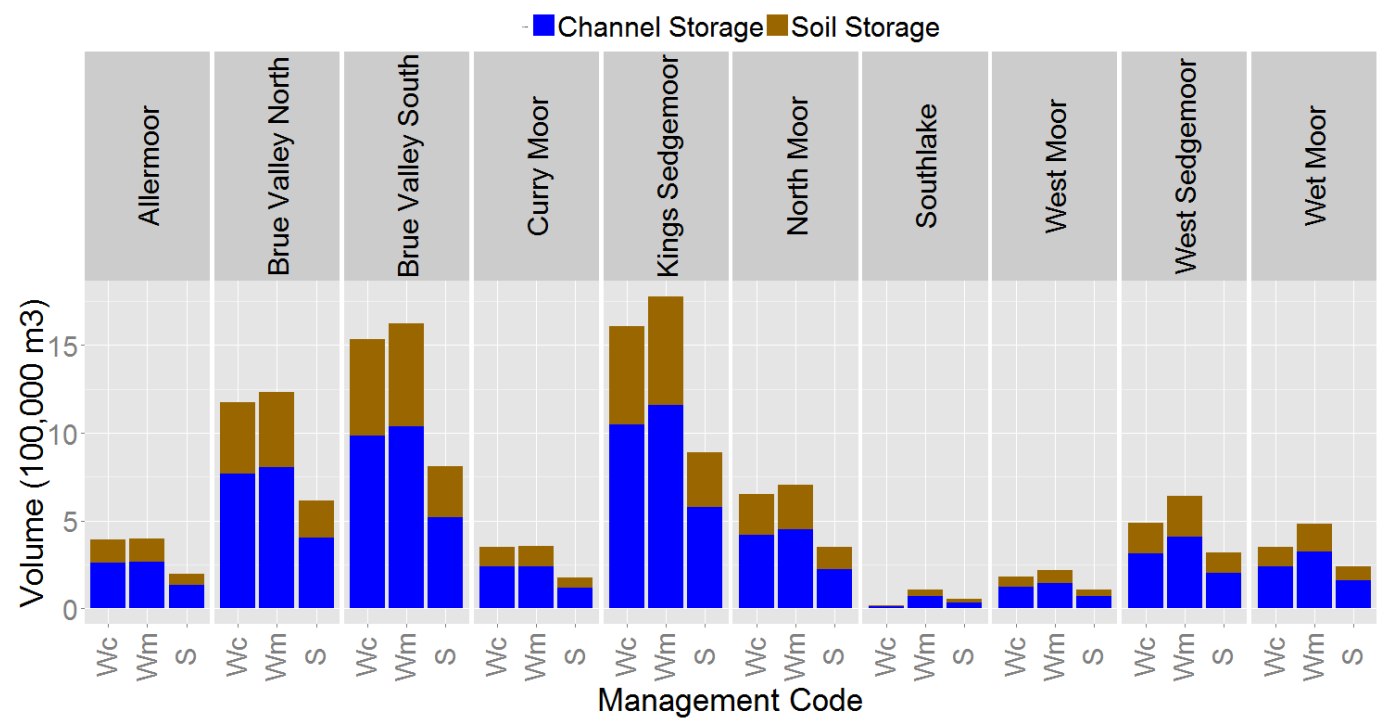

Figure 3 Ditch storage volumes for each WLMP unit under each of three water level management conditions: Winter ditch storage available under current conditions (Wc), the winter theoretical maximum ditch storage $(\mathrm{Wm})$ and summer ditch storage (S). Each bar represents the total ditch storage available under the corresponding conditions and is divided between channel storage (blue) and soil storage (brown) volumes. The distance of influence is $9 \mathrm{~m}$ and the specific yield is 0.2 . 
Summer ditch storage follows the same pattern of variability but is $50 \%$ of the maximum theoretical ditch storage (Figure 3). The management at Southlake, which is embanked and where $84.6 \%$ of ditches are RWLA, differs to that of all other units in that it is primarily used for flood storage. Comparison of the total current ditch storage with the theoretical maximum ditch storage volume provides an index of the relative impact that the raised water level areas have on the total ditch storage available. The total ditch storage volume occupied by maintenance of high water levels in winter (the difference between maximum theoretical storage and storage under current conditions) is $779,496 \mathrm{~m}^{3}$ and equates to $10 \%$ of the theoretical maximum across all sites. There is however great variability between sites from a minimum of $0.6 \%$ of the total ditch storage at Curry Moor (SLM), to $82.2 \%$ of the total ditch storage at Southlake, due to variability in the percentage of ditches managed as RWLA within each WLMP. The majority of sites have a reduction in ditch storage of between $5 \%$ and $27 \%$ due to maintenance of winter raised water levels. Summer ditch storage is $50 \%$ of the maximum theoretical ditch storage at each site. The split between channel storage and soil storage is consistent across sites with channel storage contributing approximately two thirds and soil storage contributing one third of the total ditch storage volume (Figure 3 ).

\subsection{Application to the $2013 / 2014$ floods}

Current winter ditch storage, winter theoretical maximum ditch storage volume and summer ditch storage volumes are presented in the context of the total volume of rainfall to fall on each WLMP unit during winter $13 / 14$ (

Figure 4). During the period of the Winter 2013/2014 floods, rainfall was not evenly distributed across the study area. Curry Moor received the highest rainfall $(499 \mathrm{~mm})$ and Brue Valley South received the lowest rainfall $(382 \mathrm{~mm})$; this was reflected in the extent and depth of inundation, with more severe flooding on Curry Moor. Averaged across all areas, the theoretical maximum ditch storage is $9.7 \%$, winter ditch storage is $7.8 \%$ and summer ditch storage is $4.9 \%$ of the total rainfall volume. In all except one of the WLMP areas, the ditch storage volume lost through maintenance of RWLA is $2 \%$ or less.

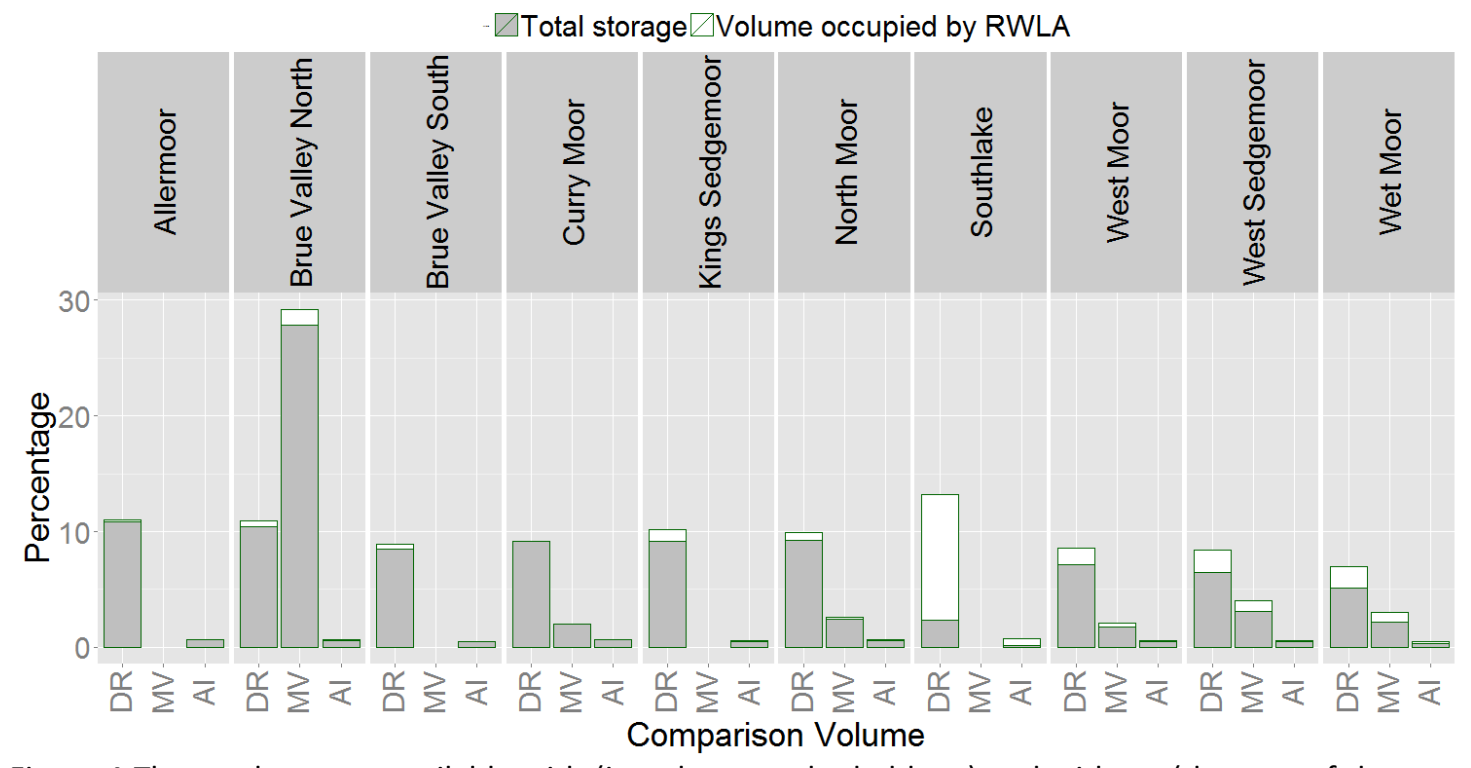

Figure 4 The total storage available with (just the grey shaded bars) and without (the sum of the grey shaded bars and the unshaded bars) RWLAs as a \% of Direct Rainfall (DR), Measured Volume (MV) and Apportioned 
Inflow (AI) for each WLMP area. In other words, the volume of storage occupied by maintenance of RWLAs is indicated by the unshaded bars.

Where data are available, the ditch storage volumes are presented in relation to estimates of maximum flood volume calculated from a combination of LiDAR-derived level to volume relationships, telemetered water-level data and remotely sensed imagery. In the six units where results exist, the average RWLA volume occupied as a percentage of the maximum flood volume in 2014 across all sites is $0.6 \%$ and the average increase in flood level across all sites is $7 \mathrm{~mm}$. Between WLMP units, the range of proportion of volume occupied is $0.01 \%$ to $1.38 \%$ and the range of flood level increase is $3 \mathrm{~mm}$ to $116 \mathrm{~mm}$. By comparison, the volume occupied by maintenance of summer penning levels is between $1.02 \%$ and $14.6 \%$ (average $3.6 \%$ ) of the maximum flood volume and this equates to an increase in flood level of between $21 \mathrm{~mm}$ and $62 \mathrm{~mm}$ (average $29 \mathrm{~mm}$ ).

The final set of calculations considers the volume of water flowing into the study area (apportioned inflows). Available river flow time-series data (from a gauging station at Lovington on the River Brue just upstream of where it enters the SLM) were scaled-up according to catchment area for the whole study area, giving and total inflow volume within the for the combined WLMP areas. The total inflow was then apportioned between each of the WLMP units. The results of this analysis show that the total volume of storage in the ditch network is less than $1 \%$ of the total flow into the area during winter $13 / 14$. The volume occupied by the maintenance of RWLAs is less than $0.13 \%$ in all areas.

\subsection{Uncertainty}

Sensitivity analysis was carried out to investigate the impact of uncertainty in specific yield and distance of influence. The winter ditch storage under current conditions and winter theoretical maximum ditch storage were calculated for combinations of specific yield ranging from 0.15 to 0.25 and distance of influence ranging from $5 \mathrm{~m}$ to $30 \mathrm{~m}$. Within each site, the most dramatic impact on total ditch storage comes from uncertainty in distance of influence. The maximum value of $30 \mathrm{~m}$ suggested by Gilman (2004), has the potential to double available the total ditch storage. Specific yield has a smaller impact on the calculated volume, with the range of possible values ( 0.15 to 0.25 ) translating to a $\sim 15 \%$ change in total ditch storage. Expressed relative to the total volume of rainfall (winter 13/14) the mean range of percentage loss in ditch storage due to maintenance of RWLA is $1.51 \%$ to $4.04 \%$.

\section{Discussion}

The results indicate that, if considered simply as a percentage of the total storage, the storage volume occupied by the RWLAs is in some WLMP areas an appreciable proportion of the total. However when expressed in relation to the volumes of water present during a severe flood event, the volumes occupied are, with one exception, less than $2 \%$. The area-wide maintenance of summer water levels represents a greater reduction in total storage than that resulting from ecologicallydriven winter water management. 
Previous studies (Acreman et al., 2007; Mould, 2008) used a similar approach to calculate storage volume of the North Drain catchment of the SLM, which is most closely approximated in this study as the sum of Brue Valley North and Brue Valley South. They calculated the available storage volume under current winter management to be $3.58 \times 10^{6} \mathrm{~m}^{3}$. By comparison our calculations for the Brue Valley North and Brue Valley South indicate a volume of $2.71 \times 10^{6} \mathrm{~m}^{3}$. A likely reason for the difference between the two is the method used to determine ditch lengths and widths. They presented this in the context of the volume of the mean annual maximum flood $\left(4.3 \mathrm{Mm}^{3}\right)$ to which the storage equates to $84 \%$. By contrast, the volumes estimated for the Brue Valley during the winter $13 / 14$ floods range are $8.5 \mathrm{Mm}^{3}$ (measured volume), $29 \mathrm{Mm}^{3}$ (direct rainfall) and $520 \mathrm{Mm}^{3}$ (apportioned inflow) depending on method used. This illustrates the unusual severity of the winter $13 / 14$ floods. The 'choice' of comparison volume clearly makes a considerable difference to the calculated values.

This is not to say that the SLM wetlands do not provide an important water storage function, rather that it is dominated by large-scale topography rather than small-scale ditch management. In the case of the winter 13/14 floods the temporary storage and subsequent release of floodwaters had the effect of reducing the maximum flood peak in the downstream water courses. The total volume of surface water stored was calculated for six WLMP areas (data availability meant that the calculation could not be made for all areas) and the volumes range from $4.2 \times 10^{6} \mathrm{~m}^{3}$ to $2.7 \times 10^{7} \mathrm{~m}^{3}$. In all but one area this equates to over double the volume of water falling as rainfall on the corresponding area during the winter $13 / 14$ study period. Storage of surface water by wetlands has been noted in other studies.

Acreman et al. (2003) present the results of modelling the impact of floodplain restoration through embankment removal, and hence increasing floodplain inundation, on flow in the River Cherwell, Oxfordshire, UK. They conclude that 'restoring the river channel through the floodplain to preengineered dimensions reduces peak flow by around $10-15 \%$ and increased peak water levels within the floodplain by 0.5-1.6 m. Embanking the river increases the peak flows downstream by up to 150\%.' Hooijer (1996) calculated that flooding of 3500 ha of floodplain in the Shannon valley, Ireland, to an average depth of $1 \mathrm{~m}$ represented a storage equivalent to one day of peak discharge (around $400 \mathrm{~m} 3 \mathrm{~s}-1$ ).

Studies in North America show similar results. Demissie and Khan (1993) reviewed and analysed the evidence for the influence of wetlands on streamflow in Illinois. They concluded that peakflow and floodflow volume decrease, and low flows increase with increasing percentage of wetlands in the watershed. More specifically, they report that wetlands have a more noticeable effect on peakflow and that the peakflow to average precipitation ratio decreased on the average by 3.7 percent for an increase of one percent wetland area in a watershed but that there were significant regional and seasonal differences in the rate of change. Novitski (1982) carried out a study of wetlands in Wisconsin. He concluded that surface-water depression wetlands, which are closest in hydrological character to those in this study, retains water and reduce flood peaks.

The value of floodplains in storing water and reducing the severity of flooding downstream is unlikely to be seen as a benefit by those people living within the flooded area. This conflict, which is by no means peculiar to SLM, is going to be the subject of environmental and socio-economic 
studies for many years as an acceptable trade-off between the requirements of key stakeholders is developed.

\section{Conclusions}

We have constructed and tested a simple model of hydrological storage for flat areas dominated by drainage ditches. The model was applied to an important wetland area in the UK to investigate the impact of water level management plans on the volume of hydrological storage available.

We tested the null hypothesis that 'raising water level in ditches in conservation areas does not reduce flood storage on the Somerset Levels and Moors'. This study concludes that the loss in ditch storage resulting from RWLAs is small in comparison to the incoming volume of water. In all except one area, the reduction in ditch storage through maintenance of summer water levels is greater than the reduction due to maintenance of RWLAs. Expressed both as a proportion of the total volume of water during the flood event and as a reduction in flood level, the calculations presented here indicate that the areas managed with raised water levels have only a very minor impact on large flood events. Above ground storage represents by far the largest component of flood water storage in the SLMs.

A considerable uncertainty in these model results is due to the highly heterogeneous character of organic peat soils and their associated hydraulic properties. We have assumed that the limited data points upon which we have based the 'extent of influence' parameter represent the whole SLMs area; however this may not be the case. Large scale field sampling would be time-consuming and expensive, and so a need exists to find ways to understand and represent this variability in a meaningful way.

Simple yet effective models are powerful tools for giving rapid 'big picture' answers to questions, and as such are attractive to decision makers. The approach presented here could be of benefit to land and drainage managers, as well as those interested in ecosystem service delivery.

\section{References}

Acreman, M.C., Mountford, J.O., McCartney, M.P., Wadsworth, R.A., Swetnam, R.D., McNeil, D.D., Manchester, S.J., Myhill, D.G., Broughton, R.K. 2002. Integrating wetland management, catchment hydrology and ecosystem functions. Final report of the $\mathrm{CEH}$ Integrating Fund Round 5. CEH Wallingford.

Acreman, M.C., Booker, D.J. \& Riddington, R. 2003 Hydrological impacts of floodplain restoration: a case study of the river Cherwell, UK. Hydrology and Earth System Sciences. 7,1, 75-86

Acreman, M.C., Miller, F. 2007 Practical approaches to hydrological assessment of wetlands lessons from the UK. In: Okruszko, T., Maltby, E., Szatyłowicz, J., Świątek, D., Kotowski, W. (eds) Wetlands; monitoring, modelling and management: Taylor \& Francis, London. 
Acreman, M.C., Fisher, J., Stratford, C.J., Mould, D.J., Mountford, J.O., 2007. Hydrological science and wetland restoration: some case studies from Europe. Hydrology and Earth System Sciences 11, 158169.

Acreman, M.C., Harding, R.J., Lloyd, C., McNamara, N.P., Mountford, J.O., Mould, D.J., Purse, B.V., Heard, M.S., Stratford, C.J., Dury, S.J., 2011. Trade-off in ecosystem services of the Somerset Levels and Moors wetlands. Hydrological Sciences Journal 56, 1543-1565.

Acreman, M.C., Holden, J.2013 Do wetlands reduce floods? Wetlands 33:773-786

Armstrong, A.C. 1993. Modelling the response of in-field water tables to ditch levels imposed for ecological aims: a theoretical analysis. Agriculture, Ecosystems and Environment. 43, 345-351.

Armstrong, A.C. and Rose, S. 1999. Ditch water levels managed for environmental aims: effects of soil water regimes. Hydrology and Earth System Sciences, 3(3), 385-394.

Boelter, D.H. 1968. Important physical properties of peat materials. Proceedings of the 3rd International Peat Congress, Quebec: 150-156.

Boelter, D. H. 1972. Water table drawdown around an open ditch in organic soils. Journal of Hydrology 15: 329-340.

Bradford, R. 2004. CEH IF Project C01795: Tadham Moor Regional Hydrological Modelling. Project

Bullock A. \& Acreman, M.C. 2003 The role of wetlands in the hydrological cycle. Hydrology and Earth System Sciences. 7,3, 75-86.Dawson, Q. 2006. Low-lying agricultural peatland sustainability under managed water regimes.

Demissie, M. \& Khan, A. 1993. Influence of wetlands on streamflow in Illinois. Contract report 561, prepared for the Illinois Department of Conservation. Illinois State Water Survey Hydrology Division Champaign, Illinois.

Gilman, K. 1994. Hydrology and wetland conservation, Wiley.

Hooijer, A. 1996. Floodplain hydrology. An ecologically oriented study of the Shannon Callows, Ireland. PhD Thesis. University of Amsterdam.

Kellner E. and Halldin S. 2002. Water budget and surface-layer water storage in a Sphagnum bog in central Sweden. Hydrological Processes 16 (1): 87-103.

Kennedy GW, and Price JS 2005. A conceptual model of volume-change controls on the hydrology of cutover peats. Journal of Hydrology 302:13 - 27

Letts, M. G., N. T. Roulet, N. T. Comer, M. R. Skarupa, and D. L. Verseghy 2000. Parametrization of peatland hydraulic properties for the Canadian Land Surface Scheme, Atmos. Ocean, 38(1), 141-160.

Meinzer OE 1923. Outline of ground-water hydrology, with definitions. US Geol Surv Water Suppl Pap 114494 
Moss, C.E. (1907). Geographical Distribution of Vegetation in Somerset: Bath and Bridgwater District. London.

Mould, D.J., 2008. Multi-scale assessment of wetland hydrological function at a wet grassland in southeast England.

Mountford, J.O., 1994. Floristic change in English grazing marshes: The impact of 150 years of drainage and land-use change. Watsonia 20, 3-24.

Muchan, K., Lewis, M., Hannaford, J. and Parry, S., 2015. The winter storms of 2013/2014 in the UK: hydrological responses and impacts. Weather 70, 55-61.

Murtedza, M., Padmanabhan, E., Mei, B.L.H. and Siong, W.B. 2002. The Peat Soils of Sarawak. STRAPEAT - Status Report.

Novitski, R. 1982. Hydrology of Wisconsin Wetlands. Information Circular 40. United States Department of the Interior, Geological Survey and University of Wisconsin - Extension: Geological and Natural History Survey, Madison, Wisconsin, U.S.A.

Parkin, G., Birkinshaw, S., Humphries, N., Benyon, P., Humphries, C., Bentley, M. and Gilman, K. 2004. Water Availability and Budgets for Wetland Restoration and Re-Creation Sites. DEFRA Commissioned Project BD1316. Final Report: June 2004.

Price, J.S. \& Schlotzhauer, M. 1999. Importance of shrinkage and compression in determining water storage changes in peat: The case of a mined peatland. Hydrol. Process, 13:2591-2601.

Swetnam, R.D., Mountford, J.O., Manchester, S.J. \& Broughton, R.K. 2004. Agri-environmental schemes: their role in reversing floral decline in the Brue floodplain, Somerset, UK. Journal of Environmental Management, 71, 79-93

Tatem, K.W. and Sturdy, I. D. 1994. Somerset levels and moors water level management and nature conservation strategy. In Wetland Management, edited by R. A. Falconer and P. Goodwin. Institution of Civil Engineers, London.

Williams, G., Hall, M., 1987. The loss of coastal grazing marshes in south and east England, with special reference to East Essex, England. Biological Conservation 39, 243-253.

Williams, M. (1970). The draining of the Somerset Levels. Cambridge.

Youngs, E.G., 1985. A simple drainage equation for predicting water-table draw downs. Journal of Agricultural Engineering Research 31, 321-328. 